\title{
Sharia Branding in Housing Context: A Study of Halal Lifestyle Representation*
}

\author{
Addin Kurnia Putri, ${ }^{1 * *}$ Yuyun Sunesti ${ }^{1}$ \\ ${ }^{1}$ Department of Sociology, Faculty of Social and Political Sciences, Universitas Sebelas \\ Maret, Surakarta - Indonesia
}

\begin{abstract}
Sharia housing has mushroomed in Indonesia in recent years. It offers a different concept of housing as the developers claim to be following Islamic values. This study analyzes how Sharia housing advertisements on social media, especially Instagram, represent the halal lifestyle. The method used in this research was a semiotic approach to analyze the signs of Sharia housing ads in the realm of digital media and its meanings. The result of the study shows that Sharia housing advertising on social media has commodified the halal concept of Sharia-based housing. The term "halal house" was also used to signify the meaning of Sharia image symbols that distinguished it from other housing. Sharia brands were also represented in advertising languages and the visualization of symbols displayed. These ads represented the halal concept not only as an image but also as a lifestyle. The halal lifestyle relating to Sharia housing has become a new trend in Muslim communities constructed through religious symbols in Sharia housing advertisements.
\end{abstract}

\begin{abstract}
Perumahan syariah telah menjamur di Indonesia dalam beberapa tahun terakhir. Developer perumahan syariah menawarkan konsep perumahan yang berbeda karena mereka mengklaim sesuai dengan nilai-nilai Islam. Tujuan dari penelitian ini adalah untuk menganalisis bagaimana iklan perumahan syariah di media sosial khususnya instagram merepresentasikan gaya hidup halal. Metode yang digunakan dalam penelitian ini adalah pendekatan semiotika untuk menganalisis tanda dalam iklan perumahan syariah di ranah media digital dan pemaknaannya. Hasil penelitian menunjukkan bahwa iklan perumahan syariah pada media sosial telah mengkomodifikasi konsep halal pada perumahan berbasis syariah. Istilah "perumahan halal" menjadi penanda makna simbol syariah yang membedakannya dari perumahan lainnya. Brand Syariah terepresentasi melalui bahasa iklan dan visualisasi simbol yang ditampilkan. Iklan-iklan ini merepresentasikan konsep halal tidak hanya sebagai brand tetapi juga sebagai gaya hidup. Gaya hidup halal yang berkaitan dengan perumahan syariah telah menjadi tren baru dalam komunitas muslim yang dibangun melalui simbol-simbol keagamaan dalam iklan perumahan syariah.
\end{abstract}

Keywords: halal lifestyle; media representation; sharia housing

*The original draft of this article has been presented on the 6th International Conference on Social and Political Sciences (ICOSAPS) 2020: "Strengthening Resilient Society in the Disruptive Era" at Universitas Sebelas Maret Surakarta, Indonesia. ${ }^{* *}$ Corresponding Author: Addin Kurnia Putri (addinkurniaputri@gmail.com), Jl. Ir. Sutami No. 36 A, Surakarta 57126 Indonesia. 


\section{Introduction}

The rise of the new rich, especially in Asia, is the rise of middle-class Muslims in urban areas (Chua 2000; Pinches 1999; Prasetyantoko 1999; Tanter and Young 1990). According to Jati (2017), the emergence of the middle-class Indonesian Muslim can be seen through two phases in socio-political events: ethical politics during the national movement and post-New Order with the emergence of urban educated people. One of the three leading indicators that shape middle-class Muslims' emergence in Indonesia is the trade economy. This indicator is the most crucial part of the middle-class Muslim's political development, which is motivated by the initiation of Muslim figures who grew from the urban middle-class base. As the regime changes to become dynamic democratization, middleclass Muslims increasingly appear in the public sphere. One of the middle-class Muslim groups, namely popular Islam, is presented as a contestation of Islamic culture in the public sphere. This group has two different faces: first, those who emphasize the teaching of Sharia values, norms, and teachings to foster Islam formalization, which creates a militant group. Second, those who respond to the capital industry's symbols or those who enjoy Islam under modernity influence. It seems that this second face also encourages the Muslim community to be interested in consuming a halal lifestyle.

Indonesia has become one of the countries with great potential to develop a significant halal industry (Mubarok and Imam 2020). Based on data from the State of the Global Islamic Economy Report (SGIER) 2020-2021, Indonesia achieved the highest record in the development of Islamic finance in 2020, by increasing the ranking of Indonesia's Islamic finance industry to 4th from 5th, after Malaysia, Saudi Arabia, and the UAE. They also noted that the consumption of a halal lifestyle in Indonesia in 2020 was the US \$ 203.2 million, the highest in Southeast Asia (Ahmed and Basit 2021).

Studies related to the halal lifestyle have been widely reviewed (Adinugraha, Sartika, and Ulama'i 2019; Mubarok and Imam 2020). The halal lifestyle is also associated with its environment with the middle class and symbolic piety (Darojatun 2018; Utama 2016). The results of more studies discuss the halal lifestyle in halal products such as halal fashion (Arianti and Purnama 2018; Taufik and Taufik 2020), halal cosmetics (Sukesi and Prasadio Akbar Hidayat 2019; Zukhrufani and Zakiy 2019), halal tourism Jayanti and Iriani 2020; Kessler 2015; Rahmah and Tapotubun 2020; Sarinastiti and Uljanatunnisa 2020), and many other studies. However, there were not many studies that discussed the issue of halal housing among the previous studies.

Several research results on sharia housing are studied in economic studies (Firmansyah and Gunardi 2018; Firmansyah and Indika 2017; Nadzifah and Fataron 2019), architecture (Mostafa and El-Basel 2020), and other scientific perspectives. There are not many socio-cultural studies regarding sharia housing and specifically related to how the halal lifestyle is represented in sharia housing advertisements.

As far as the literature review, sharia housing advertisements are still widely studied from an economic perspective. Muali and Nisa' (2019) 
examine the marketing of Islamic housing through social media as a strategic contestation to increase selling power. The results of this research indicate that a sharia marketing strategy using sharia elements is profitable. It has a major impact on the increase in consumer response and blessed profitability. Previously, the developer used a promotional strategy through print media, but the results were ineffective. Now, the business has increased through a Facebook account as a promotional medium. Social media makes it easier to convey business product information to the broader community.

Research on Isharia housing advertisement from a socio-cultural perspective is still limited. There are two studies of sharia housing advertisements that are reviewed from a sociocultural perspective (Lasman 2007; Rizki 2019). Lasman (2007) writes that identity representations in brochures and articles related to sharia housing. Lasman's study explains that consumers consume sharia housing as identity construction and become part of the Muslim community. Her study focuses on Bourdieu and Baudrillard's perspective regarding the tastes and social class in society.

Meanwhile, Rizki's research (2019) conclude that: First, the emergence of Islamic imagery as a myth which is classified into several parts, namely: Modern Muslims who are familiar with the Scriptures, Muslims who like sunnah sports riding, archery and swimming, and educated and modern Muslims. Second, Muslim identity indicates the popular Muslim Muslims and Muslim middle class. Third, developer business networks offer their products using Islamic concepts inconsistently.
This research is different from previous studies. This study focuses on the halal lifestyle represented in Sharia-based housing advertisements on social media, and the developers are commodifying religion and reproducing religious symbols through profit-oriented advertising. The theory used in this study is also different from previous related research. If Lasman (2007) has used Baudrillard and Bourdieu's Theory, Rizki (2019) has used Roland Barthes' semiotic theory. This study prefers to use Stuart Hall's theory to analyze more deeply the representation of sharia housing advertising media.

Sharia housing is one of the halal products that are currently being developed. Today, sharia-branded residences are now starting to develop. Seeing the immense potential of the Muslim market, Sharia housing developers as capitalists have commodified religious symbols. Rudnyckj (2010) argues that religion and capitalism are related and can also work together to support collective activities in the long term. Sharia-housing developers have taken control of the land and accommodated space by selling Islam's discourse symbols. Sharia housing began to develop in Indonesia, starting in the western part of Java. It can also be seen in the distribution of interest data from Google Trends in Figure 1.

Based on Figure 1, the darkest blue color shows the areas with the highest interest in sharia housing. This data supports that the sharia housing business is growing rapidly and initially developing in the West Java region, one of which can be proven by the emergence of sharia housing developer associations in this 


\section{perumahan syariah $\quad$ Google Trends}

\section{Interest by subregion. Indonesia. Past 5 years. Web Search. $\quad$ : $\quad$ :}

Figure 1

Sharia Housing Interest by Subregion. Source: Google Trends, 2020

region. The association first appeared, namely in 2014, they called themselves the Indonesian Sharia Property Developer (DPSI). The vision of DPSI is to build properties that support Islamic civilization. DPSI tries to build a brand image from the emergence of the problem of sharia housing fraud, one of which is the jargon "real sharia real project" (deloperpropertysyariah.id). Furthermore, in 2016 the Indonesian Sharia Property Association (APSI) was established. They are trying to build a bigger vision from DPSI, which is to advance the global economy with the concept of sharia business in all lines of business. APSI tries to build a good image of its products by publishing articles on fraud precautions on behalf of sharia on its website (www.apsi.or.id).
The phenomenon of Sharia housing has become increasingly prevalent in recent years. Sharia housing is a residential concept that incorporates religious elements into its practice. It can be seen in the data that appeared on Google trends for the 2015-2020 period. As seen from Figure 2, specifically, the highest search trend was in late 2019 to early 2020.

The increase in searches was traced more deeply because of the problem of "fake" Sharia housing cases or fraud that had gone viral in cyberspace. It could be seen from the related queries, which appeared the highest in Google Trends, namely fraud on Sharia housing and "fake" Sharia housing. This negative case that has emerged in public has made the Sharia housing concept a much sought-after issue to be better 
Interest over time Google Trends

perumahan syariah

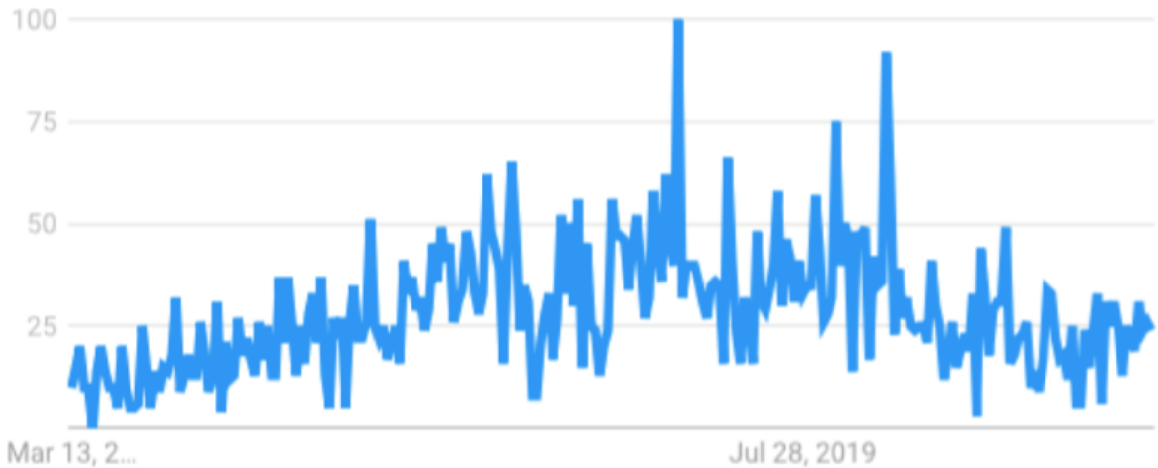

Indonesia. Past 5 years. Web Search.

Figure 2

Sharia Housing Trend. Source: Google Trends, 2020

known. The media increasingly reports on Sharia housing developers about the fraud case.

The existence of the Sharia housing fraud problem raises public distrust of this product as many media reports as Kompas.com, Kumparan.id, etc. Then, developers try to build a good image through branding marketing on advertising, one of which is through the media. For this reason, this study attempts to explore the extent to which representations of religious symbols are used in sharia housing marketing advertisements by developers. This study analyzes how developers increase consumer interest in their residential products that have been labeled with the halal concept.
This study used a semiotic method to analyze the meaning of the signs or symbols in Sharia housing advertisements, especially in Indonesia, published on social media. The social media interpreted mainly was Instagram from Sharia housing marketing. Several Instagram accounts were selected, such as @shariagreendland and @abrarlandindonesia, for further analysis using semiotics. Semiotics study signs and sign processes, from cultural representations to language, warning signs, brands, and emojis. Understanding semiotics is a valuable tool to complement other consumer insights methods, even observing the signs and their meanings. 


\section{Sharia Housing as Halal Lifestyle}

According to the Muslim Judicial Halal Trust (MJCHT), the halal lifestyle is a person's behavior carried out according to his/her abilities, truthfully, honestly, with integrity, dignity, fairness, and does not deviate from Islamic teachings (mjchalaaltrust.co.za). Many people pay attention to the lifestyle models they will live. Through a lifestyle, a person will be able to show a reflection of his personality. Likewise, Muslims' aspects of life have been regulated in Islamic teachings so that a halal lifestyle for a Muslim is an obligation/necessity as an embodiment of a Muslim's ideals (Amalia 2017).

The halal lifestyle is a lifestyle habit that is becoming a global trend and is starting to be applied in various parts. Not only are countries with Muslim populations trying to adopt this lifestyle, but countries with most non-Muslims are also vying to take this opportunity. It proves that the halal lifestyle concept has received a positive response in the national and international arena. In aggregate, the global halal industry's value is almost double compared to the Islamic finance industry. The halal industry has reached a global size of more than $\$ 2.3$ trillion in 2012, while the Islamic finance industry only surpassed \$ 1.6 trillion in 2018 (Adinugraha et al. 2019).

Muslims are more concerned with the halal concept of what they eat or what they use than the halal financial products. For example, in Russia, halal products' recognition has exceeded the limits of recognition and is now favored by all those who live a healthy lifestyle and choose halal goods because of their high quality. In Europe, the Muslim market or "halal market" experiences tremendous expansion, which has prompted many researchers and academics to engage and adapt Islamic marketing rules according to the realities of life in the West (Ameur 2011; Rachdi and Ben Ameur 2011). London's halal market remains untouched primarily as very few global corporate brands have found the key to genuinely resonating with consumers, demanding radically different engagement rules. For example, young people encourage the demand for halal beauty products that match their lifestyle and beliefs (ifdcouncil.org). Currently, the halal lifestyle has become a trend in Indonesia. Indonesia is one of the pioneers of the halal lifestyle. It is due to a large number of Indonesians who are Muslim. Therefore, Indonesia has great potential as a country that develops trends in the halal lifestyle through Sharia housing.

Based on the World Population Review data in 2020, Indonesia is a country with the largest number of Muslims globally, where an estimated 229 million people adhere to Islam. It is $87.2 \%$ of Indonesia's total population (263 million) and around $13 \%$ of the world's Muslim population (1.9 billion). Globally, Islam is the second major religion after Christianity.

The Muslim population's growth worldwide is an up-and-coming market for the halal industry from upstream to downstream, especially in Indonesia. The sustainable halal economy has been developed through various sectors to meet daily needs, such as culinary, fashion, pharmacy, media, cosmetics, tourism, education, umrah/hajj trips, zakat, Sharia financial preferences, even hospitals, and other daily activities. Apart from everyday products, the halal property sector is also starting to 
develop among investors. From there, many Sharia residences have sprung up in various cities in Indonesia. In this case, entrepreneurs have expanded their businesses using Islamic law symbols to target the Muslim consumer market. This development creates a particular lifestyle, namely the halal lifestyle that appears in the middle-class Muslim, including in the housing context currently labeled sharia housing. The concept of religious values entering the residential property business is thought to have emerged since 1995 (Lasman 2007). The Muslim market's potential, predominantly the broad middle-class, has encouraged developers to control land and commodify space using religious symbols.

In Indonesia, middle-class Muslims began to emerge in the 1920s through trade and small industry by the indigenous bourgeoisie in Central and East Java. In 1920, there was a reformation of traders in urban Java, which formed the bourgeoisie among the Muslims, who became known as middle-class Muslims (Kuntowijoyo 1991). The new middle-class lifestyle had a different appearance, especially after the Indonesian economic crisis in 1997. The pattern of consumption is one of the symbols easily recognized. The middle-class Muslim today tend to have political attitudes and consumerism (Nasr 2010).

Middle-class Muslims understand halal products and halal lifestyle obligation and demand for life to be accepted in their social life in the world and an awareness that worship can be accepted in the hereafter. It is at the same time to strengthen the symbols of piety inherent in themselves. Development halal lifestyle in the Muslim middle class, there is also the need for housing with an Islamic environment. It encourages developers to expand the market through Sharia housing products. These products are offered massively, including through social media. Acculturation of halal products and the halal lifestyle in Muslim life is increasingly lively with social media and emerging communities; the press can construct the reality of middle-class Muslims in Indonesia into individuals who are formed by the masses.

\section{Media Representation in Sharia Housing Ads}

A product can attract consumers if it has a brand. In the context of sharia housing, the symbol of Sharia becomes a brand. Branding has a place in the consumers' minds, not in the real world. Branding is not a battle to determine who can make a better product but create a better perception (Tai 2012).

Sharia branding can be interpreted as using names related to Islam or showing the halal product identity. For example, Sharia hotels, Sharia Hospital, Wardah, KFC, and others. Sharia branding is classified into three forms (Bakar, Lee, and Rungie 2013). The first is a Sharia brand with compliance. Sharia brands must show and strongly appeal to consumers by obeying and complying with Islamic Sharia. Brands that fall into this category are halal products produced by Islamic countries and are aimed at Muslim consumers. Second, the Sharia brand is based on its origin. The use of a brand without indicating the halal product comes from the country of origin of the product, known as an Islamic country. The third is Sharia branding by customers. This branding comes from nonMuslim countries, but Muslim consumers enjoy 
the products. This branding usually includes a halal label on its products to attract Muslim consumers.

According to Hall, in his book Representation: Cultural Representation and Signifying Practices, "representation connects meaning and language with culture; representation is an essential part of the process in which meaning is produced and exchanged between members of a culture." Through representation, the meaning is shaped and interchanged among society members. Thus, it can be said briefly that representation is one way to produce substance. Representation works through a representation system that consists of two essential components: concepts in mind and language. These two components are interrelated. The concept of something in people's minds makes them know its meaning, but meaning cannot be communicated without language (Hall 1997b, 1997a, 2020b, 2020a).

Therefore, the most crucial thing in this representation system is that a group that can produce and exchange meanings is a specific group with the same background knowledge to create (almost) the same understanding. According to Stuart Hall, members of the same culture must share concepts, images, and ideas to think and feel the world almost the same way. They must share, broadly, the same 'cultural code.' In this sense, thoughts and feelings are their systems of representation. Thinking and feeling, according to Hall, are also representational systems. As a representation system defined as thinking and feeling, it also functions to interpret something. Therefore, a common background in understanding the concepts, images, ideas, and cultural codes is needed.
The meaning of something can be very different in different cultures or groups because there are different ways of interpreting something in every culture or community group. Groups of people who have different backgrounds in understanding specific cultural codes will not be able to understand the meanings produced by other groups of people. Thus, it can be concluded that representation is the process of generating meaning from concepts in our minds through language. The process of producing this meaning is made possible by the existence of a representation system. However, the meaning process depends on the background knowledge and understanding of the social group about a sign. A group must have the same experience to be able to interpret things in almost the same way. In this study, the representation concept to see how religious symbols were used in Sharia housing advertisements.

Several Instagram accounts were analyzed as an intense and massive marketing medium for Islamic homes, @shariagreendland. As stated in the background, Sharia housing begins to become a trend in Indonesia, starting from the West Java region. Sharia housing associations have also begun to form in the West Java region.

Sharia green land is a Sharia housing developer based in West Java. It uses Instagram actively, seen from a very regular scale of posts. Through Instagram, it represents the concept of halal housing in the language, images, and thoughts put in the media. Sharia green land has defined Sharia housing in three aspects as one of the Sharia housing developers in Indonesia. First, ownership in Sharia with a contract without 
usury, without fines, confiscation, and insurance. Sharia house buying and selling contracts must be with fiqh mu'amalah, an agreement carried out directly between the consumer and the developer, and there may be no intermediaries or third parties. Second, Sharia housing facilities are available to be used to support individual worship and piety, such as mosques, tahfizh houses, and audio lines for listening to verses of the Qur'an and Hadith. Third, some programs are structured like studies to create collective piety. These three things are their claim to distinguish Sharia residential products from housing in general.

Religious symbols are used as advertising material in the media, such as the word "blessing", "piety", "Sunnah of the Prophet", "Islamic environment", and so on. An example can be seen in the post in the image below Sharia-housing developers try to construct a blessing concept that leads to collective piety in urban Muslim communities. Devotion and blessings are concepts in religion. They seem to guarantee their consumers on the pretext that if they buy, they will get blessings and piety. They use prophetic symbols to emphasize the Sharia house concept, creating an Islamic environment to support its residents' collective piety. In this post, it is not clear what they mean by the concept of collective piety. They have just described this concept in Figure 4.

The collective piety they build is piety or obedience, which is built not only from oneself but together with others to achieve the vision and mission they want to achieve, namely building Islamic civilization. They represent
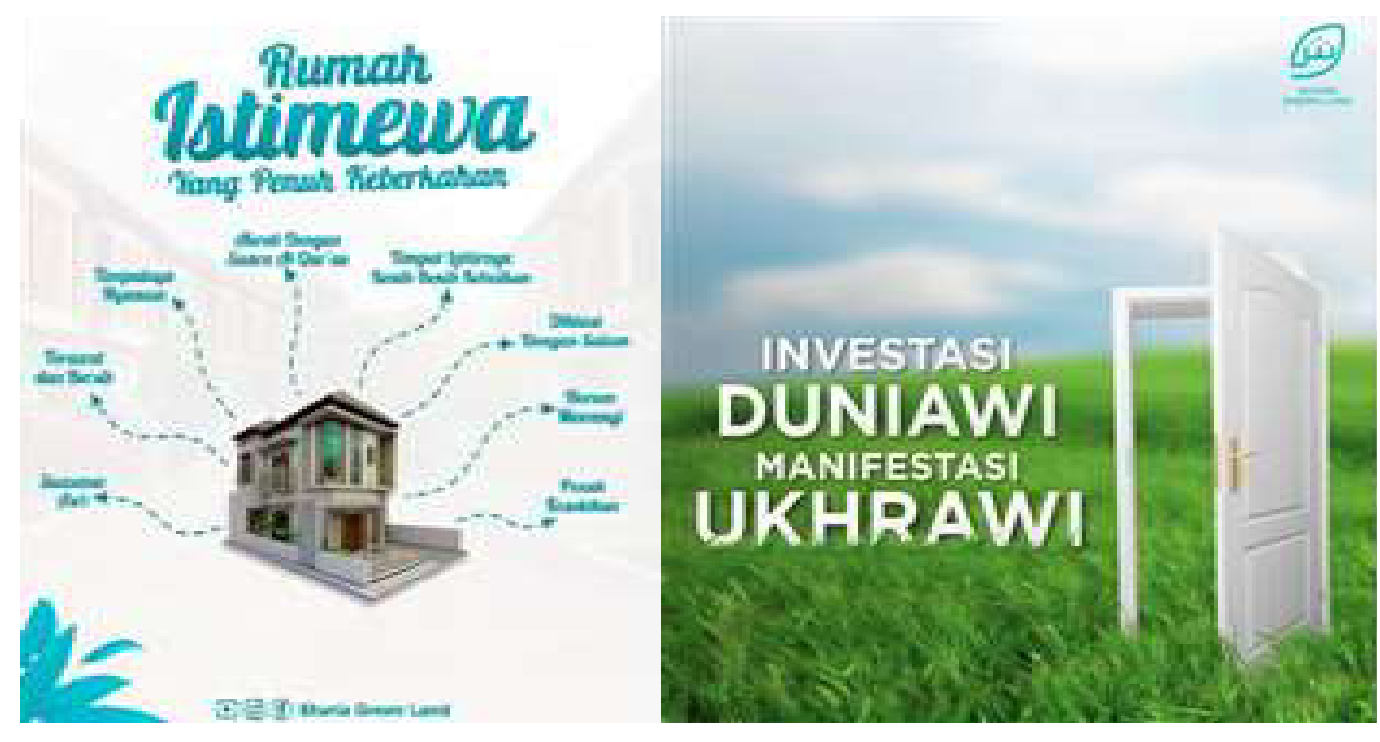

Figure 3

Language Symbol in Sharia Housing Ads source: https://www.instagram.com/shariagreenland/ 
as if by buying Sharia housing, consumers can build Islamic civilization from home. Social piety as a symbol can be understood as a form of mass popular culture ritual, namely Muslim faith and piety can be formed through the consumption of religious commodities.

Apart from language symbols, Sharia housing marketing advertisements use image symbols through models' clothes. As seen in Figure 4, it can be seen a family consisting of a father, mother, and child who wear Muslim garments. The man uses a 'koko' (the term for sharia clothes for men) dress and hat to represent Muslim men, while the women wear a robe and a hijab. According to Islamic law, the picture illustrates how the dress concept and how civilization can be built from an Islamic house. The choice of white and green colors also represents the Muslim concept conveyed through Sharia housing advertisements.
The developer also represents a design of Islamic housing starting from Islamic housing. They try to commodify Islamic values in everyday life. The concept of Islamic congregation is one of the languages to encourage consumers to apply Islamic Sharia collectively inhomogeneous housing.

The advert features fashion that reflects a Muslim's identity and shows how a Muslim lifestyle can be developed among future sharia housing residents. It is done so that prospective buyers believe that the house being sold is truly Islamic. Fashion is used in social media images as a form of promotion that uses religious symbols as social identities, Sharia symbolization is a practice of commodification of religion carried out by Sharia housing developers.

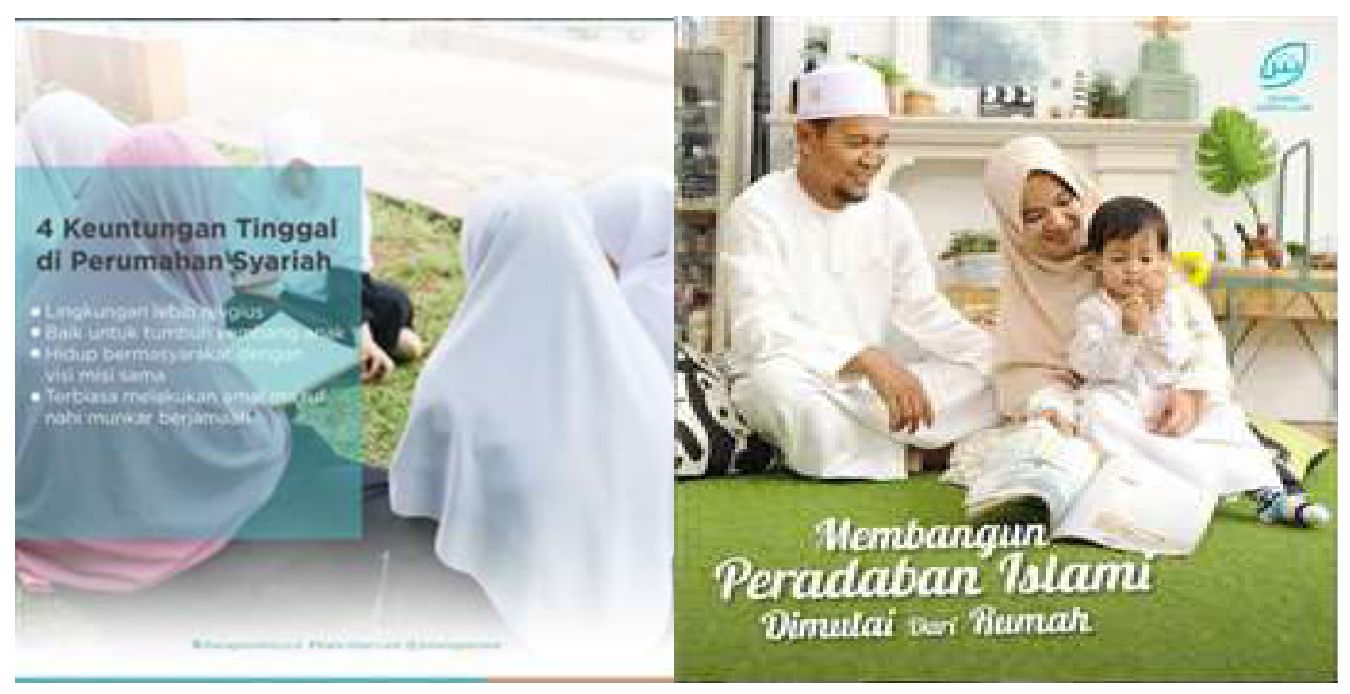

Figure 4

Sharia Housing Concept in ads

source: https://www.instagram.com/shariagreenland/ 
Sharia housing also shows exclusivity when viewed from the housing concept they developed as represented in Figure 4, namely their claim to the Sharia housing developers' product. They build the image that living in Sharia housing will get a religious environment. It is protected from harmful things, becomes a place for good children's growth and development, live together with people with the same vision and mission, and do good and avoid bad things together in the homogeneous environment. This argument shows that living outside Sharia housing is harmful and does not apply Islam in everyday life. Through advertisements, it can be analyzed that Sharia housing developers are trying to build a gated community concept for Muslim groups behind the products they promise in terms of profits.

Figure 4 also represents the Islamic environment that the developer refers to, namely, a joint Islamic study program in the congregation. In the picture, it can be seen how a group of women doing a study wearing clothes as a symbol of Islam. The developer seeks to build an image of piety and an Islamic environment intended to build a homogeneous privatization space. They build a more specific market share by accommodating consumers with similar backgrounds. The developer continues to commodify the representation of the ideal house for Muslims. They construct a homogeneous Islamic environment. It is a halal lifestyle that guarantees piety.

It can be analyzed that there has been a change in the developers' marketing strategy regarding the choice of residence. Previously, housing developers would offer consumers a strategic location and beautiful environment. But now, Islamic housing developers are selling residential concepts with a homogeneous Islamic environment. Representation of religious symbols in sharia housing advertisements is the preferred way to buy identity and become part of the Muslim community with a halal lifestyle. The homogeneous environment seems to provide comfort for residents to carry out group activities.

Its marketing is also built using religious doctrines in society, such as relating to prohibitions in religion. One developer who uses religious doctrine as marketing material is the @abrarlandindonesia Instagram account domiciled in Solo's city. This developer is a network of Sharia Housing Developers in Indonesia based on search results and content uploaded on their social media.

In contrast to the West Java region, the construction of new Sharia housing in Solo Raya is slower than in the occupied West. In Solo Raya, only the development stage can be seen from the development plans submitted on social media. Solo Raya has a relatively high Muslim market when viewed from the religion's demographic and ideological aspects formed in this area. Referring to Ahyar's (2015) study, Solo City has intense militancy to implement Islamic Sharia. It naturally leads to exclusivity so that developers use this opportunity to develop this Sharia housing product. They use religious doctrine through hadith to attract Muslim enthusiasts through ideology. Developers use religious teachings to strengthen the ideological aspects of the products they offer. 


\section{DOSA RIBA \#4}

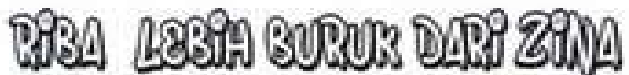

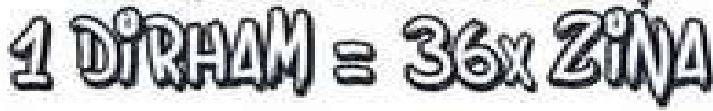

Rasulullah shallallahu falaini wa sallam bersabda,

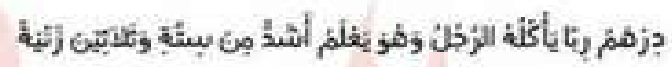

-Satu dirham yang dimakan oleh seseorang dari transaksi

riba sedangkan dia mengetahui, lebih besar dosanya daripada melakukan perbuatan zina sebanyak 36 kall."

(HR. Ahrnad dan Al Baihagi dalam Syu'abul iman. Syaikh AJ

Albani dalam Misykatul Mashobih mengatakan bahwa hadits ini shahih)

1 DIRHAM $= \pm R P .60 .000$

Figure 5

Religious Doctrine in Sharia Housing Ads

source: https://www.instagram.com/abrarlandindonesia/

The concept of Sharia-based housing advertising uses religious symbols to build a halal lifestyle in housing as a basic need for the Muslim community. Marketing using religious symbols through social media such as Instagram is a strategy for developers to sell their products. The use of religious symbols is a form of religious commodification that forms residents' identity and the image of Sharia housing, illustrating that this product is a necessity for the urban middleclass Muslim who enjoy an urban lifestyle but cannot be separated from piety and faith.

Taking Hall's (2002, 2020b) thinking, that representation is an ability to describe or imagine. In the context of this study, religious symbols in sharia housing advertisements are a form of language represented to construct meaning, one of which is the halal lifestyle. Hall divides representation into three forms, namely reflective, intentional, and constructionist representation. Sharia housing advertising can be analyzed into three forms of this approach. First, sharia housing advertising is a language product that serves as a mirror to reflect the meaning of housing following Islamic law (reflective). Second, the use of language in sharia housing advertisements is a communication medium to intervene or direct the consumer's point of view about Halal products in housing (intentional). Third, sharia housing advertising constructs the meaning of Islamic ideology through the language and symbols used (constructionist). The constructionist representation in studying the media can be analyzed from encoding and decoding. In this case, the sharia housing developer packages the idea of interpreting halal housing (encoding). 
Furthermore, How do consumer response to reconstruct the meaning of the advertisement (decoding)? So that, they are interested in the persuasion of the image of the advertising symbol. Further in-depth research is needed concerning the context of decoding.

\section{Conclusion}

Sharia housing brands develop through social media by commodifying values in religion. Sharia-housing developers use religious symbols to attract consumer interest. Sharia housing advertisements commodify religious values through the discourse of halal housing. The developer uses a halal label that represents an Islamic element as its promotional concept. The halal brand is used as legitimacy in advertisements to convince the public that Sharia housing is a halal product as the basis for applying religious law. Sharia housing advertisements have always used symbols of the halal lifestyle to target Muslim consumers. The advert represents a modern spiritual lifestyle for economic purposes. Sharia housing advertisements on social media, especially Instagram, display objects on the media and build a collective devotional identity through the image of a halal lifestyle in Muslim cities.

\section{Acknowledgment}

We would like to thank Universitas Sebelas Maret for granting us to conduct this research.!

\section{References}

Adinugraha, Hendri Hermawan, Mila Sartika, and Ahmad Hasan Asy'ari Ulama'i. 2019. "Halal Lifestyle di Indonesia." An-Nisbah: Jurnal
Ekonomi Syariah 5(2):57-81. doi: 10.21274/an.2019.6.1.57-81.

Ahmed, Tayyab, and Abdul Haseeb Basit. 2021. Global Islamic Fintech Report: Executive Summary. New York: Dinar Standard, Elipses, and Salaam Gateway.

Ahyar, Mazayyin. 2015. “Membaca Gerakan Islam Radikal dan Deradikalisasi Gerakan Islam." Walisongo: Jurnal Penelitian Sosial Keagamaan 23(1):1-26. doi: 10.21580/ ws.23.1.220.

Amalia, Dini. 2017. "Halal Lifestyle Bukan Hanya Makanan, Fashion, dan Pariwisata." Kcies.Feb.Ub.Ac.Id. Retrieved (http://kcies. feb.ub.ac.id/halal-lifestyle-bukan-hanyamakanan-fashion-dan-pariwisata/).

Ameur, Ahmed. 2011. "The Lifestyle Halal in European Marketing." Review of Economics \& Finance 1:83-90.

Arianti, Rizka Trisna, and Hadi Purnama. 2018. "Komodifikasi Kata Halal pada Iklan Hijab Zoya Versi Cantik Nyaman Halal." LISKI: Lingkar Studi Komunikasi 4(2):160-69. doi: 10.25124/liski.v4i2.1509.

Bakar, Abou, Richard Lee, and Cam Rungie. 2013. "The Effects of Religious Symbols in Product Packaging on Muslim Consumer Responses." Australasian Marketing Journal 21(3):198-204. doi: 10.1016/j.ausmj. 2013.07.002.

Chua, Beng Huat. 2000. Consumption in Asia, Lifestyle and Identities. London and New York: Routledge.

Darojatun, Rina. 2018. "Tren Produk Halal, Gaya Hidup Syar'i dan Kesalehan Simbolik: Studi Tentang Muslim Kelas Menengah." Wardah 19(2):135-57. doi: 10.19109/ wardah.v19i2.2816.

Firmansyah, Egi Arvian, and Ardi Gunardi. 2018. "A New Paradigm in Islamic Housing: NonBank Islamic Mortgage." Al-Iqtishad: Jurnal 
Ilmu Ekonomi Syariah 10(2):313-24. doi: 10.15408/aiq.v10i2.7274.

Firmansyah, Egi Arvian, and Deru R. Indika. 2017. "Kredit Pemilikan Rumah Syariah tanpa Bank: Studi di Jawa Barat." Jurnal Manajemen Teori dan Terapan 10(3):223-30. doi: 10.20473/jmtt.v10i3.6541.

Hall, Stuart. 1997a. Representation: Cultural Representations and Signifying Practices. London: SAGE Publications Ltd.

Hall, Stuart. 1997b. "Stuart Hall: Representation and the Media." in Media Education Foundation Transcript, edited by S. Talreja, S. Jhally, and M. Patierno. Northampton, MA.: Media Education Foundation.

Hall, Stuart. 2020a. "10. Culture, the Media, and the 'Ideological Effect' [1977]." Pp. 298336 in Essential Essays, Volume 1. Duke University Press.

Hall, Stuart. 2020b. "The Work of Representation." Pp. 74-76 in The Applied Theatre Reader. New York: Routledge.

Jati, Wasisto Raharjo. 2017. "Investigating the Political Base of Indonesian Middle Class: A Comparative Study." Komunitas: International Journal of Indonesian Society and Culture 9(2):267-82. doi: 10.15294/ komunitas.v9i2.6273.

Jayanti, Winka Alfi, and Sri Setyo Iriani. 2020. "What Attracts Guest to Stay? Brand Identity, Religiosity, and Reference Group towards Decision to Choose Sharia Hotel." Al-Uqud: Journal of Islamic Economics 4(1):32-47. doi: 10.26740/al-uqud.v4n1. p32-47.

Kessler, Kristel. 2015. “Conceptualizing Mosque Tourism: A Central Feature of Islamic and Religious Tourism." International Journal of Religious Tourism and Pilgrimage 3(2):11-32. doi: 10.21427/D7RB0G.

Kuntowijoyo. 1991. Paradigma Islam: Interpretasi untuk Aksi. Bandung: Mizan.
Lasman, Kartini Diah. 2007. "Representasi Identitas dalam Brosur dan Artikel Perumahan Muslim." Universitas Indonesia, Jakarta.

Mostafa, Sanagik Ibrahim, and Mai Ahmad Shaaban El-Basel. 2020. "Environment Influence on Architecture and Interior

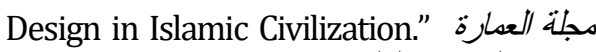
doi: 10.21608/mjaf.2019.19060.1368.

Muali, Chusnul, and Khoirun Nisa'. 2019. "Pemasaran Syariah Berbantuan Media Sosial: Kontestasi Strategis Peningkatan Daya Jual." An-Nisbah: Jurnal Ekonomi Syariah 5(2):168-85. doi: 10.21274/ an.2019.5.2.168-185.

Mubarok, Ferry Khusnul, and Muhammad Khoirul Imam. 2020. "Halal Industry in Indonesia; Challenges and Opportunities." Journal of Digital Marketing and Halal Industry 2(1):55-64. doi: 10.21580/ jdmhi.2020.2.1.5856.

Nadzifah, Millatun, and Zuhdan Ady Fataron. 2019. "Strategy Analysis of Building Sharia Residential Property Business Without Banks (A Case Study of 'Semarang Ngaliyan Residence' Syariah Housing in West Semarang)." Jurnal Ilmiah Ekonomi Islam 5(3):265-76. doi: 10.29040/ jiei.v5i3.645.

Nasr, Vali. 2010. The Rise of Islamic Capitalism: Why the New Muslim Middle Class Is the Key to Defeating Extremism. New York: The Shia Revival.

Pinches, Michael (ed). 1999. Culture and Privilege in Capitalist Asia. London and New York: Routledge.

Prasetyantoko, A. 1999. Kaum Profesional Menentang Rezim Otoriter: Sketsa tentang Kelas Menengah Indonesia. Jakarta: Grasindo. 
Rachdi, Houssem, and Ines Ghazouani Ben Ameur. 2011. "Board Characteristics, Performance and Risk-Taking Behaviour in Tunisian Banks." International Journal of Business and Management 6(6):88-97. doi: 10.5539/ijbm.v6n6p88.

Rahmah, Hilda, and Hanry Harlen Tapotubun. 2020. "Narasi Industri Pariwisata Halal di Negara Jepang dan Jerman." Jurnal Sosiologi Reflektif 14(2):287-305. doi: 10.14421/jsr.v14i2.1830.

Rizki, Bilal Prama. 2019. "Wajah Islam dalam Iklan Perumahan: Representasi Islam dalam Iklan Banner Perumahan Damai Islamic Living Yogyakarta." Universitas Islam Indonesia, Yogyakarta.

Rudnyckj, Daromir. 2010. Spiritual Economies: Islam, Globalization, and the Afterlife of Development. New York: Cornell University Press.

Sarinastiti, Eska Nia, and Uljanatunnisa Uljanatunnisa. 2020. "Strengthening EBranding Strategy of Sharia Hotel in Indonesian Hotel Industry." International Journal of Applied Sciences in Tourism and Events 4(1):48-58. doi: 10.31940/ijaste. v4i1.1910.

Sukesi, Sukesi, and Wanda Gema Prasadio Akbar Hidayat. 2019. "Managing the Halal Industry and the Purchase Intention of
Indonesian Muslims the Case of Wardah Cosmetics." Journal of Indonesian Islam 13(1):200-229. doi: 10.15642/JIIS.2019. 13.1.200-229.

Tai, Jacky Chew. 2012. Brand Management. Jakarta: Indeks.

Tanter, Richard, and Kenneth Young. 1990. The Politics of Middle-Class Indonesia. Melbourne: Monash Papers on Southeast Asia.

Taufik, M., and Amalia Taufik. 2020. "Hijrah and Pop Culture: Hijab and Other Muslim Fashions Among Students in Lombok, West Nusa Tenggara." Teosofia 8(2):97116. doi: 10.21580/tos.v8i2.5305.

Utama, Wildan Sena. 2016. "Incorporating Spirituality and Market: Islamic Sharia Business and Religious Life in Post-New Order Indonesia." Masyarakat: Jurnal Sosiologi 20(2):113-37. doi: 10.7454/mjs. v20i2.4798.

Zukhrufani, Alfitri, and Muhammad Zakiy. 2019. "The Effect of Beauty Influencer, Lifestyle, Brand Image and Halal Labelization Towards Halal Cosmetical Purchasing Decisions." Jurnal Ekonomi Dan Bisnis Islam 5(2):168-80. doi: 10.20473/jebis. v5i2.14704. 
This page has been intentionally left blank. 